\title{
THE CORRESPONDENCE OF
}
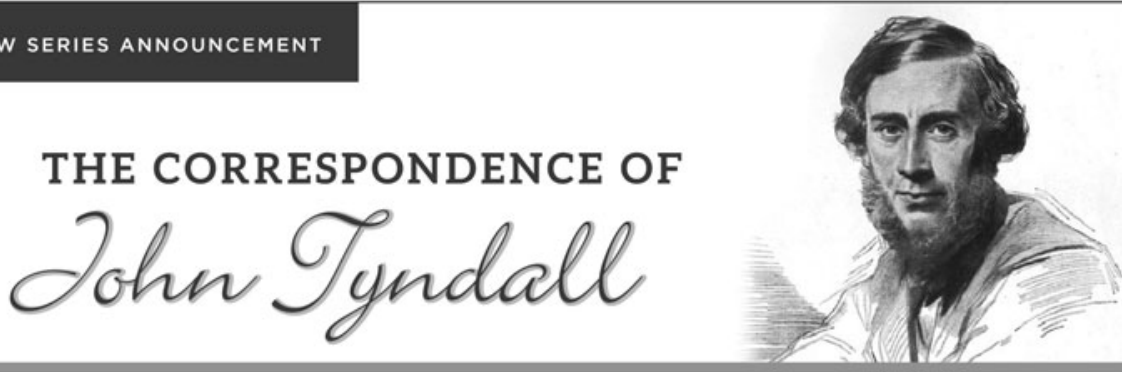

GENERAL EDITORS

James Elwick, York University | Roland Jackson, The Royal Institution Bernard Lightman, York University | Michael S. Reidy, Montana State University

The University of Pittsburgh Press is pleased to announce its new role as publisher of The Correspondence of John Tyndall, a 19-volume series that will make available for the first time in print some 7,700 letters to and from Tyndall, one of the most influential scientists and premier physicists of the Victorian era.

Tyndall's correspondents read like a who's who of international science, including Michael Faraday, Charles Darwin, Thomas Huxley, Joseph Henry, Rudolf Clausius, and Louis Pasteur. An intense study of his correspondence illuminates themes that individually and collectively played fundamental roles in the development of modern science: the relationship between science and religion, the popularization and professionalization of science, and advances in physics, glaciology, climatology, and the germ theory.

"Correspondence projects like this one undoubtedly provide rich materials for future historians-and raise a host of new questions that we might not previously have even thought to ask."

-Times Literary Supplement

\section{RECENTLY PUBLISHED}

The Correspondence of John Tyndall

Vol. 1, The Correspondence, May 1840-August 1843

Edited by Geoffrey Cantor and Gowan Dawson

$\$ 125.00 \cdot$ Hardcover • 978-0-8229-4470-6 • 544 pp.

The Correspondence of John Tyndall

Vol. 2, The Correspondence, September 1843-December 1849

Edited by Melinda Baldwin and Janet Browne

$\$ 125.00 \cdot$ Hardcover • 978-0-8229-4471-3 • 444 pp.

pittsburgh

UNIVERSITY OF PITTSBURGH PRESS
7500 Thomas Boulevard

Pittsburgh. PA 15260

upress.pitt.edu 


\section{CAMBRIDGE JUURALS}

\section{New Launch in 2016}

\section{BJHS Themes}

Published for the British Society for the History of Science

\section{A new peer-reviewed, open access, thematic journal for the history of science}

\section{Editor \\ Jon Agar, University College London, UK}

BJHS Themes is a collaborative venture between the British Society for the History of Science and Cambridge University Press aimed at establishing the first fully open access journal for the history of science community. It aims to publish open access, high-quality, scholarly, engaging collections of history of science papers, which address provocative themes, and which will be free for readers and offer no financial barrier to publication for authors. Like its sister publication, British Journal for the History of Science, BJHS Themes is a journal of the British Society for the History of Science, a major learned society for its subject.

The 1st volume will be 'Intersections: Science and Technology in Twentieth Century China and India', a focus on a history of science and technology in China and India, which will be convened by historians Jahnavi Phalkey and Tong Lam. It will be published in early 2016.

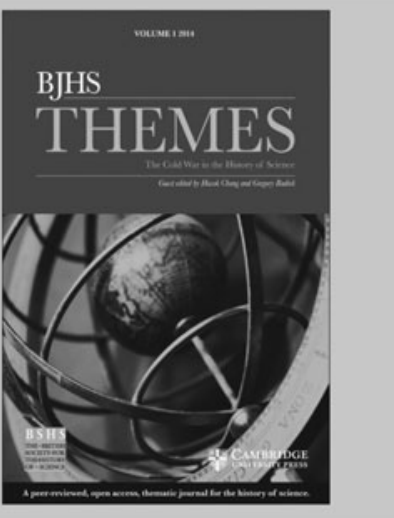

\section{BJHS Themes}

is available online at:

http://journals.cambridge.org/bjt

To subscribe contact

Customer Services

in Cambridge:

Phone $+44(0) 1223326070$

$\mathrm{Fax}+44(0) 1223325150$

Email journals@cambridge.org

\section{in New York:}

Phone +1 (845) 3537500

$\mathrm{Fax}+1(845) 3534141$

Email

subscriptions_newyork@cambridge.org

\section{Free email alerts}

Keep up-to-date with new material - sign up at

journals.cambridge.org/bjt-alerts 


\section{THE BRITISH SOGIETY FOR THE HISTORY OF SGIENGE}

Membership of the Society, which includes a subscription to The British Fournal for the History of Science, is open to all persons approved by the Council of the Society and elected at an Extraordinary General Meeting. Details of the annual subscription can be found on our website www.bshs.org.uk or from the Executive Secretary at the address below. There is an Introductory offer for the first year.

BSHS publications: BSHS Monograph Series is designed to allow the publication of monographic studies in the history of science quickly and cheaply. Monographs 1-13 are available in digital form and can be downloaded for free via the BSHS website. Monographs 12-14 are available via a print-on-demand service.

Recent titles are as follows:

Images of the Earth: Essays in the History of the Environmental Sciences. Edited by L. J. Jordanova and R. Porter. Second edition. 1997. £17.

Science in Art: Works in the National Gallery that illustrate the History of Science and Technology. By J. V. Field and F. A. J. L. James. 1997. £15.

To See the Fellowes Fight: Eye-witness accounts of meetings of the Geological Society of London and its Club, 1822-1868. By J. C.Thackray. 2003. £15.

The Society's magazine, Viewpoint, an informal publication, appears three times a year. It is free to members, $£ 12.00$ for institutions and UK non-members, 17.00 for overseas non-members from the Executive Secretary.

Administrative business of the Society is handled by Lucy Santos, Executive Secretary, British Society for the History of Science, PO Box 73631, London, SW14 9BS. The Society is registered in England as a Limited Company (No. 562208) and is a Registered Charity (No. 258854). Email office@bshs.org.uk.

Information about the Society is available through the Internet: http://www.bshs.org.uk

Copying: This journal is registered with the Copyright Clearance Center, 222 Rosewood Drive, Danvers, MA 09123. Organizations in the USA who are also registered with the CGC may therefore copy material (beyond the limits permitted by sections 107 and 108 of US copyright law) subject to payment to CGC of the per-copy fee of $\$ 12.00$. This consent does not extend to multiple copying for promotional or commercial purposes. Code 0007-0874/2016 \$12.00.

ISI Tear Sheet Service, 3501 Market Street, Philadelphia, Pennsylvania 19104, USA, is authorized to supply single copies of separate articles for private use only.

Organizations authorized by the Copyright Licensing Agency may also copy material subject to the usual conditions. Articles from the Journal in electronic form can be obtained from Cambridge Core (cambridge.org/core). Proquest (www.proquest.com) and NAPG (www.napubco.com).

For all other use, permission should be sought from Cambridge University Press or from its American branch.

Advertising: Contact the Journals Advertising Manager, Cambridge University Press, University Printing House, Shaftesbury Road, Cambridge CB2 8BS.

Back volumes a limited number of back volumes are available from BSHS Executive Secretary, PO Box 73631, London, SW14 9BS. For Volume 24 onwards, apply to Cambridge University Press in printed form.

Information on the British fournal for the History of Science and all other Cambridge journals can be accessed via cambridge.org/bjh

Claims for missing issues should be made immediately on receipt of the subsequent issue.

This journal issue has been printed on FSC-certified paper and cover board. FSC is an independent, non-governmental, not-for-profit organization established to promote the responsible management of the world's forests. Please see www.fsc.org for information.

\section{Printed in the United Kingdom by Bell E Bain}




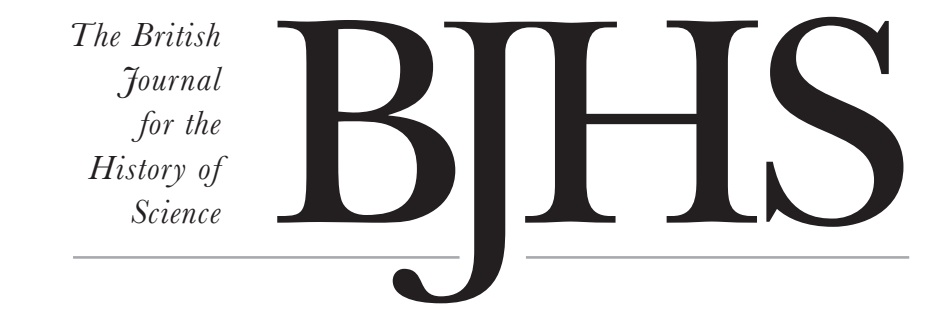

Volume 49

Part 4 No. 183 December 2016

Owning Health: Medicine and Anglo-American Patent Gultures A Special issue

Guest editor: James F. Stark

533 Introduction: plurality in patenting: medical technology and cultures of protection JAMES F. STARK

541 Authority and ownership: the growth and wilting of medicine patenting in Georgian England

ALAN MACKINTOSH

561 Honour and subsistence: invention, credit and surgery in the nineteenth century SALLY FRAMPTON

577 Pharmaceutical patenting and the transformation of American medical ethics JOSEPH M. GABRIEL

601 A barrier to medical treatment? British medical practitioners, medical appliances and the patent controversy, 1870-1920

CLAIRE L. JONES

627 Essay review - A pathology of progress? Locating the historiography of cancer AGNES ARNOLD-FORSTER

635 Book reviews

\section{B S H S \\ THE BRITISH \\ SOCIETY FOR \\ THE HISTORY \\ OF SCIENCE}

Published for The British Society for the History of Science

by Cambridge University Press 